Jurnal Sulolipu : Media Komunikasi Sivitas Akademika dan Masyarakat

Vol. 19 No. 12019

e-issn : 2622-6960, p-issn : 0854-624X

\title{
PEMANFAATAN AIR KELAPA (COCOS NUCIFERA L) SEBAGAI AKTIVATOR PEMBUATAN KOMPOS SISA SAYURAN DAN LIMBAH AMPAS TEH Juherah $^{1}$ dan Riska Hamsah ${ }^{2}$ \\ 1.2Jurusan Kesehatan Lingkungan Poltekkes Kemenkes Makassar \\ kesling.mks@gmail.com
}

\begin{abstract}
Waste is unwanted residual material after the end of a process. One of the uses of waste is composting. Making compost from the rest of the vegetables with the addition of tea pulp waste provides many benefits for human life. Waste that was not valuable, after being processed, can be reused through an economically valuable recycling process. The purpose of this research is to determine the ability of coconut water activator Cocus nucifera L) in composting fast. This type of research is an experimental study by conducting trials on organic waste using activators from coconut water (cocus nucifera L), the study consisted of two variations of coconut water concentration (Cocos nucifera L) that is $250 \mathrm{ml}$, and $100 \mathrm{ml}$ and its control. The results showed that the coconut water activator with a concentration of $250 \mathrm{ml}$ was able to decompose organic waste for 25 days with a final $\mathrm{C} / \mathrm{N}$ ratio of 10 , whereas the coconut water activator with a concentration of $100 \mathrm{ml}$ was able to decompose organic waste for 28 days with a final $\mathrm{C} / \mathrm{N}$ ratio of 11 , and the control is able to decompose organic waste for 28 days with a final $\mathrm{C} / \mathrm{N}$ Ratio 19. Based on the results obtained it can be concluded that the compost meets SNI standards: 19-7030-2004, where the maximum C/N ratio in compost is 10 and the maximum value of the $\mathrm{C} / \mathrm{N}$ ratio, is 20 .
\end{abstract}

Keywords: Leftover vegetables, dregs Tea, Coconut Water and Compost

\section{ABSTRAK}

Sampah merupakan material sisa yang tidak diinginkan setelah berakhirnya suatu proses. Salah satu pemanfaatan sampah adalah dengan pembuatan kompos. Pembuatan kompos dari sisa sayuran dengan penambahan limbah ampas teh banyak memberikan keuntungan bagi kehidupan manusia. Limbah yang semula tidak berharga, setelah diolah dapat dimanfaatkan kembali melalui proses daurulang yang bernilai ekonomis. Tujuan penelitian Untuk Mengetahui Kemampuan Aktivator Air Kelapa (cocus nucifera L) Dalam Mepercepat Pengomposan.Jenis penelitian ini adalah penelitian eksperimen dengan melakukan uji coba pada sampah organik dengan menggunakan Aktivator dari air kelapa (cocus nucifera $L$ ), penelitian terdiri dari dua variasi konsentrasi air kelapa (Cocos Nucifera L) yaitu $250 \mathrm{ml}$, dan $100 \mathrm{ml}$ serta kontrolnya. Hasil penelitian menunjukkan bahwa Aktivator air kelapa dengan konsentrasi $250 \mathrm{ml}$ mampu mendekomposisi sampah organik selama 25 hari dengan C/N Rasio akhir 10, Sedangkan Aktivator air kelapa dengan konsentrasi $100 \mathrm{ml}$ mampu mendekomposisi sampah organik selama 28 hari dengan C/N Ratio akhir 11, dan Kontrol mampu mendekomposisi sampah organik selama 28 hari dengan C/N Ratio akhir 19. Berdasarkan hasil yang didapatkan dapat disimpulkan bahwa kompos telah memenuhi standar SNI : 19-7030-2004 dimana untuk maksimum C/N ratio pada kompos yaitu 10 dan nilai maksimal C/N ratio yaitu 20 .

Kata kunci : Sisa Sayuran, Ampas Teh, Air Kelapa dan Kompos

\section{PENDAHULUAN}

Menurut American Public Health Association, sampah (waster) diartiakan sebagai sesuatu yang tidak digunakan,tidak terpakai,tidak disenangi atau sesuatu yang dibuang,yang berasal dari kegiatan manusia dan tidak terjadi dengan sendirinya

Permasalahan sampah menjadi semakin krusial, dari data didapatkan bahwa potensi sampah kota di Indonesia meningkat dari hari ke hari seiring dengan pertambahan penduduk. Pada volume sampah meningkat, menjadi 100.000 ton per hari, sedangkan untuk kondisi sampah kota yang, dihasilkan oleh beberapa kota seperti Jakarta 10.220 ton per hari, Surakarta menghasilkan sampah kota sebesar 267 ton per hari, Semarang menghasilkan 727 ton per hari dan Mangelang menghasilkan 63 ton per hari. (Sudrajat, 2006), dari sekian banyak sampah kota yang dihasilkan tersebut sampah plastik yang menjadi permasalahan utama mempunyai sumbangan sebesar $2 \%$ sehingga dalam satu hari dapat dihasilkan 2.000 ton perhari (Sudrajat 2006). Berdasarkan profil Kota Makassar menerangkan bahwa tingkat timbulan sampah sebanyak 0,0035 m3/orang/hari, Kota Makassar dengan jumlah penduduk 1.160.011 jiwa, menghasilkan $4.060 .03 \mathrm{~m} 3$. Jumlah ini didapatkan dari jumlah penduduk $0.0035 \mathrm{~m} 3 /$ orang/hari. Sampah yang terangkut saat ini sebanyak 3251,74 m3. Sehingga banyaknya sampah yang belum terlayani adalah $808,29 \mathrm{~m} 3$. Sumber sampah di perkotaan yang terbanyak dari pemukiman dan pasar tradisional. Sampah pasar sebagian besar (95\%) berupa organik, dan sampah yang berasal dari pemukiman umumnya sangat beragam, tetapi secara umum minimal $75 \%$ terdiri dari sampah organik. (Sudrajat, 2006)

Limbah sayuran merupakan material sisa yang tidak di inginkan setelah berakhirnya suatu proses atau kegiatan. Limbah padat dari buangan pasar dihasilkan dalam jumlah yang cukup besar, hanya ditumpuk di tempat pembuangan dan 
Jurnal Sulolipu : Media Komunikasi Sivitas Akademika dan Masyarakat

Vol. 19 No.12019

e-issn : 2622-6960, p-issn : 0854-624X

selanjutnya dibuang ke TPA jika tumpukan sudah meninggi. Penumpukan limbah padat yang terlalu lama dapat mengakibatkan pencemaran, yaitu bersarangnya hama-hama dan timbulnya bau yang tidak diinginkan. Pengolahan limbah padat berupa sayur-sayuran ini perlu dilakukan, salah satu cara mengolah limbah padat ini adalah dengan pembuatan pupuk kompos.

\section{BAHAN DAN METODE}

\section{Lokasi Penelitian}

Penelitian dilakukan di laboratarium Terapan Jurusan Kesehatan Lingkungan Poltekkes Kemenkes Makassar.

\section{Desain dan Variabel Penelitian}

a. Desain

Kompos merupakan pupuk yang dibuat dari sampah organik yang sebagian besar berasal dari rumah tangga. Kompos adalah bahan organik yang bisa lapuk, seperti daun-daunan, sampah dapur, jerami, rumput, dan kotoran lain, yang semua itu berguna untuk keseburan tanah. Kompos menjadi alternatife terbaik dalam pemanfaatan sampah yang terjadi disekitar kita. Dengan memilah sampah dan mengolah secara tepat Waktu kematangan kompos menurut persyaratan SN I-7030-2004. Kompos umumnya mengalami kematangan pada hari ke-30

b. Variabel Penelitian

Variabel bebas dalam penelitian ini adalah

C/N Ratio, penambahan Aktivator Air Kelapa (Cocos nicifera L) $250 \mathrm{ml}$, penambahan aktivator Air Kelapa (cocos nucifera L) $100 \mathrm{ml}$, tanpa penambahan Aktivator Air Kelapa (Cocos nucifera L).

\section{Metode Pengumpulan Data}

a. Data Primer

Data primer Merupakan data yang diperoleh dari hasil penelitian dalam proses pembuatan kompos, termasuk juga pengukuran dan kelembaban yang dilakukan setiap hari

b. Data Sekunder

Data yang diperoleh dari hasil studi perpustakaan, buku-buku dan internet yang ada hubungannya dengan obyek penelitian.

c. Teknik Analisa Data

Data yang diperoleh berdasarkan hasil pengamatan yang didapat pada saat melaksanakan eksperimen kemudian diolah secara manual dan dianalisa secara deskriptif. d. Teknik Penyajian Data

Pengolahan data dilakukan dengan mikrosoft office word dan hasil penelitian disajikan dalam bentuk tabel, kemudian dijelaskan secara deskriptif.

HASIL

1. Hasi Pengukuran Dengan Aktivator $250 \mathrm{ml}$ Tabel 1

Hasil Pengukuran Suhu Dengan Aktivator 250 ml Pada Pembuatan Kompos Sisa Sayuran dan Ampas Teh

\begin{tabular}{|c|c|c|c|}
\hline No & Jenis Bahan & Hari Ke- & Suhu \\
\hline \multirow[t]{4}{*}{1.} & Sisa & $1-4$ & $35^{\circ} \mathrm{C}$ \\
\hline & $\begin{array}{l}\text { Sayuran+ } \\
\text { Ampas Teh }\end{array}$ & 5-10 & $37^{\circ} \mathrm{C}$ \\
\hline & & $10-17$ & $32 \stackrel{\circ}{ } \mathrm{C}$ \\
\hline & & $17-25$ & $29 \stackrel{\circ}{\mathrm{C}}$ \\
\hline
\end{tabular}

Tabel 2

Hasil Pengukuran Kelembaban Dengan Aktivator $\mathbf{2 5 0} \mathrm{ml}$ Pada Pembuatan Kompos Sisa Sayuran dan Ampas Teh

\begin{tabular}{llcc}
\hline No & Jenis Bahan & Hari Ke- & Kelembaban \\
\hline 1. & Sisa & $1-6$ & $90 \%$ \\
& Sayuran + & $6-8$ & $95 \%$ \\
& Ampas Teh & $6-13$ & $80 \%$ \\
& & $13-18$ & $75 \%$ \\
& & $18-20$ & $70 \%$ \\
& & $20-25$ & $60 \%$ \\
\hline
\end{tabular}

Tabel 3

Hasil Pengukuran C/N Ratio Dengan Aktivator $250 \mathrm{ml}$ Pada Pembuatan Kompos Sisa Sayuran dan Ampas Teh

\begin{tabular}{llcc}
\hline No & Jenis Bahan & Sebelum & Sesudah \\
\hline 1. & Sisa Sayuran + & 29,0 & 10 \\
& Ampas Teh & & \\
\hline
\end{tabular}


Jurnal Sulolipu : Media Komunikasi Sivitas Akademika dan Masyarakat

Vol. 19 No.1 2019

e-issn : 2622-6960, p-issn : 0854-624X

\section{Hasil Pengukuran Dengan Aktivator $\mathbf{1 0 0 ~ m l}$}

Tabel 4

Hasil Pengukuran Suhu Dengan Aktivator 100 ml Pada Pembuatan Kompos Sisa Sayuran dan Ampas Teh

\begin{tabular}{llll}
\hline No & $\begin{array}{l}\text { Jenis } \\
\text { Bahan }\end{array}$ & Hari Ke- & Suhu \\
\hline 1. & $\begin{array}{c}\text { Sisa } \\
\text { Sayuran+ } \\
\text { Ampas } \\
\text { Teh }\end{array}$ & $1-8$ & $35^{\circ} \mathrm{C}$ \\
& $13-13$ & $30^{\circ} \mathrm{C}$ \\
& $27^{\circ} \mathrm{C}$ \\
\hline
\end{tabular}

Tabel 5

Hasil Pengukuran Kelembaban Dengan Aktivator $\mathbf{1 0 0} \mathrm{ml}$ Pada Pembuatan Kompos Sisa Sayuran dan Ampas Teh

\begin{tabular}{llll}
\hline No & Jenis Bahan & $\begin{array}{l}\text { Hari } \\
\text { Ke }\end{array}$ & Kelembaban \\
\hline 1. & Sisa & $1-8$ & $85 \%$ \\
& Sayuran+ & & \\
& Ampas Teh & $8-17$ & $80 \%$ \\
& & $17-20$ & $75 \%$ \\
& & $20-25$ & $65 \%$ \\
& & $25-28$ & $60 \%$ \\
\hline
\end{tabular}

Tabel 6

Hasil Pengukuran C/N Ratio Dengan Aktivator 100 ml Pada Pembuatan Kompos Sisa Sayuran dan Ampas Teh

\begin{tabular}{llll}
\hline No & $\begin{array}{l}\text { Jenis } \\
\text { Bahan }\end{array}$ & Sebelum & Sesudah \\
\hline 1. & Sisa & 29,0 & 11 \\
& Sayuran & & \\
& + Ampas & & \\
& Teh & &
\end{tabular}

3. Hasil Pengkuran Tanpa Aktivator (Kontrol)

Tabel 7

Hasil Pengukuran Suhu Tanpa Aktivator Pada Pembuatan Kompos Sisa Sayuran dan Ampas Teh

\begin{tabular}{|c|c|c|c|}
\hline No & $\begin{array}{l}\text { Jenis } \\
\text { Bahan }\end{array}$ & Hari Ke & Suhu \\
\hline \multirow{5}{*}{$\begin{array}{l}1 . \\
+\end{array}$} & Sisa Sayuran & 01-Jun & $35^{\circ} \mathrm{C}$ \\
\hline & Ampas Teh & Jun-15 & $40 \stackrel{\circ}{C}$ \\
\hline & & $15-18$ & $35 \stackrel{\circ}{C}$ \\
\hline & & $18-25$ & $30 \stackrel{\circ}{C}$ \\
\hline & & $25-28$ & $29 \stackrel{\circ}{C}$ \\
\hline
\end{tabular}

Tabel 8

Hasil Pengukuran Kelembaban Tanpa Aktivator Pada Pembuatan Kompos Sisa Sayuran dan Ampas Teh

\begin{tabular}{llll}
\hline No & Jenis Bahan & $\begin{array}{l}\text { Hari } \\
\text { Ke }\end{array}$ & Kelembaban \\
\hline 1. & Sisa Sayuran + & $1-7$ & $70 \%$ \\
& Ampas Teh & $7-13$ & $80 \%$ \\
& & $13-20$ & $75 \%$ \\
& & $20-26$ & $65 \%$ \\
& & $26-28$ & $60 \%$ \\
\hline
\end{tabular}

Tabel 4.8

Hasil Pengukuran C/N Ratio Tanpa Aktivator Pada Pembuatan Kompos Sisa Sayuran dan Ampas Teh

\begin{tabular}{llll}
\hline No & Jenis Bahan & Sebelum & Sesudah \\
\hline 1. & $\begin{array}{l}\text { Sisa Sayuran }+ \\
\text { Ampas Teh }\end{array}$ & 29,0 & 19 \\
\hline
\end{tabular}

\section{PEMBAHASAN}

1. Pengomposan Dengan Aktivator $250 \mathrm{ml}$

Nilai rata-rata hasil pengukuran suhu pada kompos selama 25 hari dengan bahan sisa sayuran dan ampas teh yaitu $35^{\circ} \mathrm{C}$ hal ini kemungkinan terjadi karena bahan yang digunakan dalam proses pengomposan belum terurai dengan baik. Pada awal pengomposan $37^{\circ} \mathrm{C}$ sampai akhir pengomposan $29^{\circ} \mathrm{C}$, suhu dalam proses pengomposan mulai naik 
Jurnal Sulolipu : Media Komunikasi Sivitas Akademika dan Masyarakat

Vol. 19 No.12019

e-issn : 2622-6960, p-issn : 0854-624X

peningkatan suhu merupakan indicator adanya proses dekomposisi sebagai akibat hubungan kadar air dan kerja mikroorganisme, pada hari ke5 suhu mencapai sampai $37^{\circ} \mathrm{C}$ hal ini disebabkan karna masih adanya aktivitas mikroorganisme pada kompos yang bekerja lebih aktif sehingga suhu meninggkat, namun suhu Pada hari ke-10 sampai hari ke-17 suhu dalam proses pengomposan mulai menurun hingga $32^{\circ} \mathrm{C}$, setelah suhu mulai menurun maka mikroorganisme mesophilic kembali aktif, kondisi tersebut belum menunjukkan kematangan kompos. Pada hari ke-17 sampai hari ke-25 suhu kompos mulai menurun dari sampai $29^{\circ} \mathrm{C}$ setelah suhu stabil proses pematangan kompos terjadi, kondisi tersebut menunjukkan bahwa sudah ada salah satu ciri dari kematangan kompos yaitu Ada beberapa faktor yang dapat mempengaruhi turunnya suhu pada kompos, diantaranya karena kondisi lingkungan sekitar dan adanya perlakuan kompos yang sering dibuka atau dianginkan.

Nilai rata-rata hasil pengukuran kelembaban selama 25 hari pada kompos sisa sayuran dengan campuran ampas teh menunjukkan adanya kenaikan kelembaban, bahkan mengalami peningkatan $90 \%$. Secara umum kelembaban yang baik untuk berlangsungnya proses dekomposisi secara aerobik adalah 40-60\% dengan tingkat terbaik $50 \%$ hal ini terjadi karena karakter bahan organik ampas teh memiliki kadar air yang cukup tinggi dan penyiraman dengan aktivator Air Kelapa sebanyak $250 \mathrm{ml}$, Pada proses penelitian dengan menggunakan limbah air kelapa sebagai aktivator memiliki kandungan air yang cukup tinggi, fosfor $(P)$ serta kalium yang berfungsi dalam proses fotosintesis, pengangkutan hasil asimilasi, enzim dan mineral termasuk air serta meningkatkan daya tahan/kekebalan tanaman terhadap penyakit. Fosfor merupakan unsur yang terkandung didalam air kelapa, fosfor ini sangat baik bagi tanaman karena dapat memicu pertumbuhan batang tanaman, semakin banyak air kelapa yang digunakan dalam tanaman akan semakin banyak kandungan fosfor yang terkandung didalamnya. Namun pada penelitian ini kembali dapat diturunkan hingga 60\% dengan adanya perlakuan terhadap kompos yang sering diaduk dan diangin-anginkan.

Berdasarkan hasil diatas, nilai $\mathrm{C} / \mathrm{N}$ ratio telah memenuhi persyaratan serta standar SNI: 19-7-32004 yakni nilai $\mathrm{C} / \mathrm{N}$ ratio pada kompos adalah minimum 30 dan maksimum 40 . Dengan diperolehnya nilai hasil tersebut, kompos sudah dapat digunakan untuk tanaman maupun dalam hal penyuburan tanah, karena karbon dan nitrogen yang diperoleh sangat diperlukan oleh tanaman dalam proses penyuburan tanah.

2. Pengomposan Dengan Aktivator $100 \mathrm{ml}$

Berdasarkan nilai rata-rata suhu pada kompos, pada hari ke-1 sampai hari ke-8 suhu meningkat sampai di atas $35^{\circ} \mathrm{C}$, hal ini disebabkan karena bahan yang digunakan dalam proses pengomposan belum mampu terurai dengan sempurna karena masih dalam tahap awal pengomposan dan suhu akan kembali meningkat sampai bahan baku yang didekomposisi oleh mikroorganisme habis dari situ suhu akan turun kembali. Pada hari ke-8 sampai hari ke-13 suhu dalam proses pengomposan mulai menurun hingga $30^{\circ} \mathrm{C}$, meski telah mengalami penurunan suhu, kondisi tersebut belum menunjukkan kematangan kompos. Pada hari ke-14 sampai hari ke-20 suhu kompos mulai naik sampai $32^{\circ} \mathrm{C}$, hal disebabkan karna proses pengomposan belum mampu terurai dengan sempurna, pada hari ke-20 sampai hari ke-28 suhu kompos mulai menurun hingga $30^{\circ} \mathrm{C}$, hal tersebut dikarenakan kondisi tersebut menunjukkan bahwa sudah ada salah satu ciri dari kematangan kompos yaitu mendakati suhu kamar $\left(25^{\circ} \mathrm{C}\right)$. Ada beberapa faktor yang dapat mempengaruhi turunnya suhu pada kompos, diantaranya karena kondisi lingkungan sekitar dan adanya perlakuan kompos yang sering dibuka atau dianginkan.

Berdasarkan nilai rata-rata kelembaban pada kompos, pada hari ke-1 sampai hari ke-8 kelembaban meningkat sampai diatas $85 \%$, hal disebabkan karena bahan yang digunakan dalam proses pengomposan belum mampu terurai dengan sempurna karena masih dalam tahap awal pengomposan. Pada hari ke-8 sampai hari ke-17 kelembaban sudah mulai menurun sampai $80 \%$, hal ini disebabkan karena secara perlahan kompos sudah mulai terurai karena pengadukan yang dilakukan setiap hari, pada hari ke-17 sampai hari ke-20 kelembaban mulai menurun hingga mencapai $75 \%$ dan pada hari ke-20 sampai hari ke-28 kelembaban sudah mencapai $60 \%$ kondisi tersebut sudah menunjukkan kematangan kompos dimana tekstur kompos sudah renyah dan tidak menggumpal dan kelembaban yang stabil dalam kompos yang sudah matang berkisaran antara 40 $\%-60 \%$ adalah kisaran optimum untuk metabolism mikroba apabila kelembaban dibawah 40\% aktivitas mikroba akan mengalami penurunan dan akan lebih rendah lagi pada kelembaban $15 \%$. Apabila kelembaban lebih besar dari $60 \%$ hara akan tercuci, volume udara berkurang, akibatnya aktivitas mikroba akan menurun dan akan terjadi fermentasi anaerobik yang menimbulkan bau tidak 
Jurnal Sulolipu : Media Komunikasi Sivitas Akademika dan Masyarakat

Vol. 19 No.12019

e-issn : 2622-6960, p-issn : 0854-624X

sedap (Nur Muhammad, 2013). Namun pada penelitian ini kembali dapat diturunkan hingga $60 \%$ dengan adanya perlakuan terhadap kompos yang sering diaduk dan diangin-anginkan.

Pada hasil akhir pengomposan yang sudah matang, bahan organik mentah telah terkomposisi setelah melewati beberapa proses dan waktu yang cukup lama akan membentuk produk kompos yang stabil. Untuk mengetahui tingkat kematangan kompos ditinjau berdasarkan ratio dapat dilakukan dengan diuji di laboratarium. Sebelum pelaksanaan penelitian, telah diketahui $\mathrm{C} / \mathrm{N}$ ratio awal pada campuran beberapa bahan organik yaitu 29,0 dan berdasarkan uji hasil laboratarium, pada akhir pembuatan kompos diperoleh nilai COrganik:43,70 N-Total 4,11 dan C/N yaitu 11 .

3. Pengomposan Tanpa Aktivator (Kontrol)

Nilai rata-rata hasil pengukuran suhu pada kompos selama 28 hari, sisa sayuran dengan campuran limbah ampas teh pada hari ke-1 sampai hari ke-6 suhu awal pengomposan yaitu $35^{\circ} \mathrm{C}$, hal ini kemungkinan terjadi karena bahan yang digunakan dalam proses pengomposan belum terurai dengan baik. Pada hari ke- 6 sampai hari ke-15 suhu mulai naik kembali hal ini disebabkan karena masih adanya aktivitas mikroorganisme pada kompos yang bekerja lebih aktif sehingga suhu meningkat. Suhu harus dijaga tidak terlampau tinggi selama pengomposan selalu timbul panas sehingga bahan organik yang dikomposkan temperaturnya naik bahkan sering mencapai $60^{\circ} \mathrm{C}$. pada suhu tersebut mikrobia mati atau sedikit sekali yang hidup untuk menurunkan suhu umumnya dilakukan pembalikan timbunan bakal kompos. Pada hari ke-18-25 suhu sudah mulai menurun hingga $30^{\circ} \mathrm{C}$ dan pada hari ke- 25 sampai hari ke-28 suhu sudah mulai menurun sampai $29^{\circ} \mathrm{C}$ setelah suhu stabil proses pematangan kompos terjadi, kondisi tersebut menunjukkan bahwa sudah ada salah satu ciri dari kematangan kompos yaitu ada beberapa faktor yang dapat mempengaruhi turunnya suhu pada kompos, diantaranya karena kondisi lingkungan sekitar dan adanya perlakuan kompos yang sering dibuka atau dianginkan.

Nilai rata-rata hasil pengukuran kelembaban selama 28 hari pada kompos sisa sayuran dengan campuran ampas teh menunjukkan adanya ketidak stabilan kelembaban yang baik untuk berlangsungnya proses dekomposisi secara aerob adalah $40-60 \%$ dengan tingkat terbaik $50 \%$ pada penelitian ini, kembali dapat di turunkan hingga $60 \%$ dengan adanya perlakuanterhadap kompos yang sering diaduk dan dianginkan.
Berdasarkan hasil $\mathrm{C} / \mathrm{N}$ Ratio Untuk mengetahui tingkat kematangan kompos ditinjau berdasarkan ratio dapat dilakukan dengan diuji di laboratarium. Sebelum pelaksanaan penelitian, telah diketahui $\mathrm{C} / \mathrm{N}$ ratio awal pada campuran beberapa bahan organik yaitu 29,0 dan berdasarkan uji hasil laboratarium, pada akhir pembuatan kompos diperoleh nilai COrganik:44,40 N-Total 2,35 dan C/N yaitu 19. Berdasarkan hasil diatas, nilai $\mathrm{C} / \mathrm{N}$ ratio telah memenuhi persyaratan serta standar SNI: 19-7-32004 yakni nilai $\mathrm{C} / \mathrm{N}$ ratio pada kompos adalah minimum 30 dan maksimum 40 . Dengan diperolehnya nilai hasil tersebut, kompos sudah dapat digunakan untuk tanaman maupun dalam hal penyuburan tanah, karena karbon dan nitrogen yang diperoleh sangat diperlukan oleh tanaman dalam proses penyuburan tanah.

Adapun kelebihan dari penelitian ini dibandingkan dengan Aktivator $100 \mathrm{ml}$ dan kontrol pada aktivator $250 \mathrm{ml}$ diperoleh lama waktu kematangan kompos yaitu 25 hari dengan kualitas kompos yang bagus dan sesuai dengan SNI, sedangkan untuk aktivator $100 \mathrm{ml}$ dan kontrol diperoleh waktu 28 hari hal ini disebabkan karena pemakaian aktivator yang banyak namun biasa juga tidak memakai aktivator atau tanpa perlakuan tetapi waktu yang diperoleh cukup lama

\section{KESIMPULAN DAN SARAN}

\section{Kesimpulan}

Dari hasil penelitian disimpulkan sebagai berikut:

a. Hasil kompos yang diperoleh telah memenuhi standar SNI:19-7030-2004 yaitu $\mathrm{C} / \mathrm{N}$ ratio untuk aktivator $250 \mathrm{ml}$ yaitu 10 dengan suhu akhir $29 \stackrel{\circ}{\circ}$ dengan kelembaban akhir $60 \%$, aktivator $100 \mathrm{ml}$ yaitu C/N Ratio 11, suhu akhir $27^{\circ} \mathrm{C}$ dengan kelembaban $60 \%$, dan tanpa aktivator C/N Ratio 19, suhu akhir $29{ }^{\circ} \mathrm{C}$ dengan kelembaban akhir $60 \%$. Untuk maksimum $\mathrm{C} / \mathrm{N}$ ratio pada kompos yaitu 10 dan nilai maksimal $\mathrm{C} / \mathrm{N}$ ratio 25, suhu kompos yang telah matang berkisaran $30-60^{\circ} \mathrm{C}$, dan kelembaban $40-60 \%$.

b. Aktivator air kelapa (Cocos Nucifera L) $250 \mathrm{ml}$ mampu mendekomposisi sampah organik Selama 25 hari.

c. Aktivator air kelapa (Cocos Nucifera L) $100 \mathrm{ml}$ mampu mendekomposisi sampah organik selama 28 hari.

d. Pengomposan tanpa aktivator mampu mendekomposisi sampah organik 
Jurnal Sulolipu : Media Komunikasi Sivitas Akademika dan Masyarakat

Vol. 19 No.12019

e-issn : 2622-6960, p-issn : 0854-624X

selama 28 hari. Diantara ke tiga perlakuan tersebut maka pada perlakuan pertama yaitu penggunaan aktivator 250 ml mampu mendekomposisi sampah organik selama 25 hari dengan kualitas kompos yang bagus dan sesuai dengan SNI.

2. Saran

a. Hasil penelitian ini diharapkan dapat menjadi salah satu alternative pengendalian sampah organik sebagai bahan utama dalam pembuatan kompos.

b. Perlu adanya kesadaran masyarakat tentang pemanfaatan sampah organik menjadi kompos, sehingga dapat meminimalisir volume sampah dilingkungan dengan cara memanfaatkan sisa-sisa sayuran yang banyak dipasar

\section{Daftar Pustaka}

Dewi, 2017. Pemanfaatan limbah Organik Pasar Sebagai Bahan Pupuk Kompos Untuk Penghijauan Masyarakat., Universitas Muhammadiyah Cirebon: http://lpp.uad.al.id/wp.conten/uploads/2017/05/27.dewi.Diakses Tanggal 1 Januari 2017.

Indriani Yovita Hety, 2011. Membuat Kompos, Secara Kilat. Jakarta: Swadaya.

Kurniati Y, 2010. Komposisi Buah Kelapa (Cocos Nucifera L). http://digilib.unila.ac.id/1510/6/13. Diakses Tanggal 2 Januari 2018.

Khalimatu Nisa, dkk, 2016. Memproduksi kompos mikroorganisme Lokal (MOL). Jakarta Timur: Bibit Publisher.

Nur Muhammad, 2013. Pengolahan Sampah Organik Dengan Tambahan Aktivator Ananas Comasus L Merr dalam pembuatan kompos. Program Diploma III Jurusan Kesehatan Lingkungan Poltekkes Makassar. (KTI tidak dipublikasikan).

Prasojo Suminaring, 2012. Memupuk Uang Dari Sampah. Jakarta Timur: Bestari. 